\author{
ROBERT KOŁODZIEJ* \\ Instytut Historyczny \\ Uniwersytet Wrocławski \\ ORCID: 0000-0002-3900-6667
}

\title{
SENAT JAKO STAN SEJMOWY W CZASACH JANA III SOBIESKIEGO
}

\section{The Senate as a parliamentary estate during the times of John III Sobieski \\ Abstract}

The article discusses selected elements in the functioning of the Senate as a parliamentary estate during the time of John III Sobieski. Actually, the turnout of Senators was higher than at the times of the Vasas. Senators traditionally participated in the work of the Sejm court, committees and provincial sessions; their role increased in drafting constitutions, which were created at the time of the conclusions. The involvement of Senators in current political disputes was not conducive to maintaining neutrality so important for noble political activists, who wanted to see the Senate as an "intermediary estate" between the king and the nobility. Although there are no radical anti-senatorial speeches, there is no increase in the authority of the Senate as an institution.

Keywords: Commonwealth of Both Nations, John III Sobieski, Sejm, Senate, Senate councils

\begin{abstract}
Abstrakt
Artykuł omawia wybrane elementy w funkcjonowaniu senatu jako stanu sejmowego w czasach Jana III Sobieskiego. W omawianym czasie frekwencja senatorska była wyższa niż w czasach Wazów. Senatorowie tradycyjnie brali udział w pracach sądu sejmowego, deputacjach i sesjach prowincji, wzrasta ich rola w spisywaniu projektów konstytucji, powstających wówczas w czasie konkluzji. Angażowanie się senatorów w bieżące spory polityczne nie sprzyjało zachowaniu neutralności, tak ważnej dla szlacheckich statystów, którzy chcieli widzieć w senacie „stan pośredniczący” między królem a narodem szlacheckim. Choć nie
\end{abstract}

\footnotetext{
Dr hab. Robert Kołodziej, prof. Uniwersytetu Wrocławskiego - pracownik Instytutu Historycznego Uniwersytetu Wrocławskiego. Zajmuje się dziejami ustroju Rzeczypospolitej Obojga Narodów, historią dyplomacji, kultury politycznej oraz edytorstwem źródeł historycznych. W obszarze jego zainteresowań leżą również dzieje wewnętrzne Rzeczypospolitej w XVII wieku. E-mail: robert.kolodziej@uwr.edu.pl.
} 
dochodzi wówczas do radykalnych antysenatorskich wystąpień, nie można zauważyć wzrostu autorytetu senatu jako instytucji.

Słowa kluczowe: Jan III Sobieski, senat, sejm, Rzeczpospolita Obojga Narodów, rady senatu

Funkcjonowanie senatu w czasach Jana III Sobieskiego nie było jak dotąd obiektem osobnych, wyczerpujących rozważań, choć pewne elementy związane z działalnością tego ważnego organu ustrojowego Rzeczypospolitej były już sygnalizowane przez historyków ${ }^{1}$. Przede wszystkim warto zwrócić uwagę na fakt, że w omawianym okresie zmienia się skład senatu, który uszczuplony został o czterech senatorów inflanckich. Stało się tak na mocy konstytucji z 1677 r., reformującej strukturę urzędniczą Inflant ${ }^{2}$. Na jej mocy w miejsce dawno nieobsadzonych i faktycznie wygaszonych urzędów wojewodów i kasztelanów dorpackich, parnawskich i wendeńskich stworzono nowe urzędy senatorskie: wojewodę oraz kasztelana inflanckich ${ }^{3}$. Przy Inflantach pozostał urząd senatora duchownego, zmieniła się jednak jego tytulatura, gdyż biskupa wendeńskiego przemianowano na biskupa inflanckiego ${ }^{4}$. W ten sposób senat został uszczuplony ze 150 do 146 urzędów ${ }^{5}$. Senatorów było zawsze o jednego mniej niż urzędów (oczywiście nie licząc urzędów wakujących), bowiem jeden z biskupów koronnych pełnił równocześnie funkcję pieczętarza. W 1681 r. król zamierzał oddać wakujący urząd podkanclerzego litewskiego Mikołajowi Pacowi biskupowi wileńskiemu. Skumulowanie biskupstwa wileńskiego z pieczęcią litewską sprawiłoby, iż liczba senatorów w stosunku do urzędów zmniejszyłaby się o kolejną osobę (144 senatorów obsadzałoby 146 urzędów). Ostatecznie do nominacji nie doszło, prawdopodobnie król wycofał się pod wpływem protestów posłów litewskich, którzy powoływali się na fakt, iż na Litwie nie było nigdy zwyczaju nadawania pieczęci biskupom ${ }^{6}$.

Senatorowie w trakcie trwania sejmu występowali w dwojakiej roli-jako stan sejmowy oraz jako rada królewska. Rolą rady królewskiej, która funkcjonowała nie tylko w czasie sejmów, było przede wszystkim organizowanie posiedzeń rad senatu, a także przyjmowanie

\footnotetext{
1 K. Matwijowski, Senat w czasach Jana III Sobieskiego, w: Senat w Polsce. Dzieje i teraźniejszość, red. K. Matwijowski, J. Pietrzak, Warszawa 1993, s. 117-124; J. Krupa, Rady senatu za Jana III Sobieskiego (1674-1696), „Studia Historyczne”, 35/1992, s. 305-329; analizowano również frekwencję senatorów na sejmach, zob. J. Maroń, Udział senatorów w obradach sejmowych za panowania Jana III Sobieskiego, w: Senat w Polsce..., s. 221-231; idem, Senatorowie na sejmach Jana III, w: Z przeszłości Rzeczypospolitej w czasach nowożytnych, red. K. Matwijowski, S. Ochmann-Staniszewska, B. Rok, Wrocław 1998, „Prace Historyczne”, t. 25, s. 46-64; R. Kołodziej, „, Ostatni wolności naszej klejnot”. Sejm Rzeczypospolitej za panowania Jana III Sobieskiego, Poznań 2014, s. 655-664; studium prozopograficzne dotyczące wybranych senatorów (bez senatorów duchownych oraz senatorów z W. Ks. Lit.) w omawianym okresie, zob. S. Ciara, Senatorowie i dygnitarze koronni w drugiej połowie XVII wieku, Wrocław-Warszawa-Kraków 1990.

2 „Ordynacya Xięstwa Inflantskiego”, Volumina Legum, wyd. J. Ohryzko (dalej: VL), t. 5, Petersburg 1860, s. 237.

Ibidem; Urzędnicy inflanccy XVI-XVIII w. Spisy, opr. K. Mikulski, A. Rachuba, Kórnik 1994, s. 15-16.

S. Kutrzeba, Skład sejmu polskiego 1493-1793, „Przegląd Historyczny”, 2/1906, s. 43-76.

J. Pietrzak, Senat Rzeczypospolitej Polskiej. Tradycja i współczesność XV-XXI w., Warszawa 2010, s. 16.

A. Rachuba, Pac Mikołaj Stefan h. Gozdawa, w: Polski Stownik Biograficzny, t. 24, Wrocław-Warszawa-Kraków-Gdańsk 1979, s. 740; o proteście litewskim autor diariusza sejmowego pisał w ten sposób: „wnieśli po tym ichm. panowie litewscy, aby pieczęć mniejsza W. Ks. Lit. spirituali nemini cedat, bo byśmy w tym wielkie cierpieli praeiudicium", zob. Diariusz sejmu sześćniedzielnego warszawskiego roku Pańskiego 1681, die 14 ianuarii zaczęty, BCz., 178, s. 401-402.
} 
poselstw i udzielanie audiencji, przede wszystkim posłom cudzoziemskim. Poza sejmem senat (rada królewska) występował w mocno okrojonym składzie, często król ograniczał się do zwoływania tzw. „senatu przytomnego”, czyli tych, którzy przebywali akurat na dworze. Z tego powodu w radach udział brało najczęściej kilkanaście osób ${ }^{7}$. Wyjątkiem była wielka rada senatu zwołana do Warszawy w 1680 r., w której wzięło udział 41 senatorów i oczywiście licznie obsadzane rady posejmowe.

Jako jeden z trzech stanów sejmowych występowali senatorowie w związku z funkcjonowaniem sejmu i byli oni istotnym elementem niemal na każdym etapie obrad, zarówno w fazie stanów połączonych, jak i rozłączonych. Posiadanie silnego oparcia w senacie było ważnym elementem polityki królewskiej, bo wsparcie ze strony autorytetu „braci starszych” w trakcie trwania sejmu było nie do przecenienia. Dlatego królom zdarzało się gorąco wzywać senatorów na obrady sejmowe i niektórzy z nich wprost deklarowali, że zjawiali się na sejmie za wyraźną wolą monarchy. Jędrzej Potocki przybył do Warszawy w 1683 r. na rozkaz króla, pomimo tego, iż chorował jego syn ${ }^{8}$. „Gorąca prośba” władcy była powodem przybycia na sejm w 1689 r. Piotra Opalińskiego wojewody brzeskiego i Wojciecha Konstantego Brezy wojewody kaliskiego 9 . Zdarzały się jednak również sytuacje odwrotne, gdy współpracownicy monarchy dawali niektórym senatorom do zrozumienia, że ich obecność na sejmie nie jest mile widziana. Dotyczyło to oczywiście tych nielicznych przedstawicieli opozycji, którzy pozwalali sobie na otwarte czy nawet zawoalowane wystąpienia przeciw królowi. W czasach Jana III do grupy takich osób należał Jan Chryzostom Pieniążek wojewoda sieradzki, którego w 1688 r. nakłaniano, aby nie przyjeżdżał na sejm do Grodna ${ }^{10}$. Ostatecznie wojewoda na sejmie się pojawił, a na posejmowej radzie senatu wygłosił mowę będącą atakiem na politykę monarchy ${ }^{11}$. Już kilka dni później zwolennicy dworu nakłonili go do szybkiego opuszczenia Grodna ${ }^{12}$.

Królewskie działania miały pewien, raczej niewielki wpływ na kształtowanie frekwencji senatorskiej w czasie sejmów, ważniejsze były jednak inne czynniki, takie jak wewnętrzna i zagraniczna sytuacja polityczna kraju czy nawet pora roku i stan dróg. W czasach Jana III Sobieskiego doszedł kolejny element, mający z pewnością negatywny wpływ na frekwencję, związany z organizowaniem sejmów w Grodnie. Zarówno duża odległość miasta od części prowincji koronnych, jak i niewystarczające zaplecze bytowe nie zachęcały do przybywania na sejmy organizowane w Wielkim Księstwie ${ }^{13}$.

\footnotetext{
J. Krupa, op. cyt., s. 305-329.

8 Jędrzej Potocki do NN podczaszego wiskiego, Stanisławów, 20 I 1683, AGAD, APP, 315, s. 44.

9 Considerationes i memoriale pewne [Piotra Opalińskiego], BUW, 47, s. 92.

10 Michał Warszycki miecznik koronny do J. Ch. Pieniążka wojewody sieradzkiego, w zamku pileckim, 24 IV 1688 r., BOss., 1767, s. 226-227; oczywiście ze względu na niewystarczający stan zachowania źródeł trudno oszacować skalę tego zjawiska, jednak nie można wykluczyć, że takie ,propozycje” były składane również i innym osobom.

11 AGAD, AR II, ks. 29, s. 14-25.

12 Oficjalnym powodem wyjazdu była choroba małżonki, ale w jednym z listów Pieniążek dawał otwarcie do zrozumienia, że za wyjazdem stała ,niełaska króla”, zob. J. Pieniążek do [Marcina Oborskiego kasztelana podlaskiego?], b.m. 28 IV 1688, BOss., 1767, s. 210-211.

13 Jednym z senatorów otwarcie deklarującym, że na sejmy do Grodna nie będzie jeździł, był Andrzej Trzebicki biskup krakowski, krytykujący sam pomysł organizowania sejmów w W. Ks. Lit., zob. A. Trzebicki do Michała Kazimierza Paca woj. wileńskiego, hetmana w. lit., Warszawa, 1 V 1677, BCz., 175, s. 195.
} 
Niezależnie od wszystkich czynników kształtujących frekwencję senatorską ${ }^{14}$, jej analiza i wszystkie, nawet przybliżone obliczenia, obarczone są ryzykiem sporych błędów. Wynika to oczywiście z ułomności zachowanego materiału źródłowego. Z trudności takich badań zdawali sobie sprawę historycy zajmujący się dziejami senatu w czasach nowożytnych ${ }^{15}$. Z konieczności liczeni są jedynie ci, którzy pojawiali się w źródłach, głównie na kartach diariuszy sejmowych, korespondencji lub pamiętników. Jak dalece zawodne mogą być jednak obliczenia, doskonale dokumentuje przykład sejmu z 1681 r. Dzięki źródłom opisującym przebieg obrad udało się ustalić nazwiska 37 senatorów obecnych na sejmie. Tymczasem z relacji naocznego świadka wiadomo, że w Warszawie zjawiło się ich wówczas aż 73 i że było ich tak wielu, że podczas posiedzeń zasiadali w dwóch rzędach ${ }^{16}$. Na marginesie warto dodać, iż wota wygłosiło wówczas jedynie 16 senatorów i był to najniższy wynik dla całego okresu panowania Jana III. Często obserwatorzy obrad nie uważali za stosowne odnotowywać pobytu niektórych senatorów, tym bardziej, że wielu z nich przybywało do miasta sejmowego na krótki czas i uczestniczyło w niewielkiej liczbie posiedzeń. Wprawdzie już w czasach Wazów senatorowie z różnych powodów spóźniali się na wota, jednak w czasach Jana III pojawiła się na szeroką skalę nowa tendencja, związana z opuszczaniem przez parlamentarzystów miasta sejmowego jeszcze przed zakończeniem obrad. Było to z pewnością związane $\mathrm{z}$ wyjątkowo długim sejmowaniem w omawianym okresie ${ }^{17}$, co przekładało się na wysokie koszty utrzymania. Ale były i inne przyczyny, których przykładów znanych jest w źródłach wiele. Jan Antoni Chrapowicki wojewoda witebski kilka razy uczestniczył jedynie we fragmentach sejmów, wyjeżdżając dla załatwiania spraw majątkowych. Senatorowie wyjeżdżali też na Trybunał, aby pilnować toczących się tam procesów. Nierzadko za wcześniejszym przyjazdem lub wyjazdem stały powody polityczne. Poróżniony z dworem Jan Kazimierz Sapieha w 1685 r. przybył do Warszawy spóźniony, by kilka dni po inauguracji obrad wyjechać, pod pretekstem choroby żony. Że była to tylko wymówka, wiadomo z relacji dobrze zorientowanego pamiętnikarza, który zapisał, że „ta choroba była smutnie spraktykowana przez jego [Sapiehę] na wiernej sobie małżonce"18. Znacznie spóźniony w $1685 \mathrm{r}$. przybył, obrażony na króla za pominięcie go przy nominacji na urząd kanclerza, podkanclerzy litewski Dominik Radziwiłł. Podkanclerzy koronny Michał Radziejowski w 1688 r. bardzo niespiesznie jechał do Grodna, co stało się podstawą do plotek, że nie chciał oddać pieczęci mniejszej koronnej, którą musiał złożyć po otrzymaniu awansu na arcybiskupstwo gnieźnieńskie $^{19}$. Ale nawet ci senatorowie, którzy byli obecni w mieście sejmowym, nie

14 Przegląd dyskusji nad metodologią obliczeń frekwencji senatorskiej przedstawił J. Dąbrowski, Senat koronny. Stan sejmujący w czasach Jana Kazimierza, Kraków 2000, s. 11-13; analizę tychże zagadnień dla czasów Władysława IV zob. A. Korytko, „, Na których opiera się Rzeczpospolita”. Senatorowie koronni za Władysława IV Wazy, Olsztyn 2015, s. 91-107.

15 Ostatnio na ten temat: J. Dąbrowski, op. cit., s. 13; A. Korytko, op. cit., s. 108.

16 Jan Antonii Chrapowicki, Diariusz, Muzeum Narodowe w Krakowie, 169, t. 6, s. 94.

17 Sejmy niejednokrotnie zamiast ustawowych sześciu ciągnęły się ponad piętnaście tygodni, zob. R. Kołodziej, „Ostatni wolności naszej klejnot”..., s. 62, tab. 3.

18 J. A. Chrapowicki, op. cit., t. 7, s. 213.

19 R. Kawecki, Kardynat Michat Stefan Radziejowski (1645-1705), Opole 2005, s. 59. Radziejowski swój niespieszny przyjazd tłumaczył na różne sposoby, a to chorobą, a to docierającymi do niego plotkami o rychłym zerwaniu sejmu, a to skargą na brak dobrej gospody. Jednak najciekawsze z thumaczeń to konieczność przestrzegania postu: „Ja bym już się zbliżył ku Grodnowi, gdyby nie dni mięsopusnte, które do negocjacyjej nie są”, zob. M. Radziejowski do Stanisława Szczuki, z Reszel, 24 II 1688, AGAD, APP, 163, t. 3, s. 143-147; M. Radziejowski do Tomasza Romanowskiego chorążego chełmskiego, w Resku, 12 II 1688, AGAD, AR V, 12776, s. 16-17. 
uczestniczyli regularnie w obradach. Trudno wyobrazić sobie, że pod koniec pierwszego sejmu grodzieńskiego w mieście pozostało tylko pięciu senatorów, a tylu właśnie obecnych było na sali w dniu 18 marca 1679 r. ${ }^{20}$ Dlatego trudno ocenić, ilu senatorów w omawianym okresie w rzeczywistości pojawiało się na sejmach. Dużo bardziej wiarygodne dane można wyciągnąć z porównania senatorów wotujących, bo w ich przypadku zachowane informacje są dużo bardziej rzetelne i kompletne. Jak zatem wyglądała frekwencja podczas wotów senatorskich w omawianym okresie na tle czasów wcześniejszych?21

W czasach Zygmunta III średnia wotujących to ponad 15 senatorów ${ }^{22}$. Dla Władysława IV rzetelne dane dotyczą jedynie senatorów koronnych, których wotowało niemal 13\% ${ }^{23}$. Gdyby analogicznie dodać do tego podobny (lub nieco wyższy) procent senatorów litewskich, w liczbach bezwzględnych uzyskano by wynik około 20 wotujących senatorów na sejm. Nieco mniej mogło wygłaszać wota na sejmach nadzwyczajnych, co potwierdzają obliczenia Przemysława Paradowskiego, według którego było to średnio około 17 senatorów ${ }^{24}$. Średnia wotujących na 17 sejmach (na dwóch sejmach wota się nie odbyły) z czasów Jana Kazimierza dla wszystkich senatorów była nieznacznie niższa i wynosiła około 18 osób ${ }^{25}$. Zatem, według prowizorycznych obliczeń, liczba wotujących w czasach Wazów wahała się między 15 a 20 senatorami. Na tym tle liczba wotujących senatorów w czasach Jana III przedstawia się imponująco i wynosi średnio 26 osób na sejm. Jednak należy dodać tu dwie ważne uwagi mające pewien wpływ na obliczenia. Statystykę zawyża sejm koronacyjny, kiedy aż 48 senatorów wygłosiło swoje wota ${ }^{26}$. Dodatkowo średnią obliczono jedynie na podstawie 7 z 12 sejmów z omawianych czasów, bowiem tylko na tylu sejmach wota odbyły się bez przeszkód i zdążyli zabrać głos wszyscy obecni. Dwukrotnie wota nie zostały dokończone ze względu na brak czasu (podczas sejmów z lat 1685 i 1688-1689), a na trzech sejmach (w latach 1688, 1693, 1695) wotów w ogóle nie było. Gdyby jednak wota na sejmach 1685 i 1688-1689 odbyły się normalnym trybem, mogłyby one dodatkowo zawyżyć statystykę, gdyż na obu tych sejmach zebrało się bardzo wielu senatorów. Dość wspomnieć, że w 1685 r. w wotach wzięło udział 17 senatorów, ale zakończono je po głosach zaledwie dwóch kasztelanów, a przed wotami

20 Na sesji 18 III 1679 r. w izbie obecni byli jedynie podskarbi koronny J. A. Morsztyn, podkanclerzy koronny J. Małachowski, wojewoda poznański K. Grzymułtowski, wojewoda ruski S. J. Jabłonowski i wojewoda pomorski W. Denhoff, zob. Diariusz sejmu walnego grodzieńskiego w W. Ks. Lit. ab inchoatione die 15 decembris 1678 anno, BCz., 176, s. 552.

21 Porównanie nie obejmuje czasów Michała Korybuta, ponieważ brak opracowań na ten temat. Najnowsza publikacja obejmująca krótkie biogramy senatorów zob. L. Wierzbicki, Senatorowie koronni na sejmach Rzeczypospolitej w XVII wieku, Warszawa 2017; niestety autor w wykazach nie uwzględnił wygłaszanych wotów.

22 W. Czapliński, A. Filipczak-Kocur, Udział senatorów w pracach sejmowych za Zygmunta III i Władysława IV, „Przegląd Historyczny”, 69/1978, s. 670-675.

23 A. Korytko, op. cit., s. 128; wykazy wszystkich senatorów z omawianych czasów zestawiła S. Hołdys, Praktyka parlamentarna za panowania Władystawa IV, Wrocław 1991, jednak przedstawione w książce dane wymagają gruntownych korekt.

24 Obliczenia własne na podstawie P. Paradowski, ,, W obliczu nagłych potrzeb” Rzeczypospolitej. Sejmy ekstraordynaryjne za panowania Władysława IV Wazy, Toruń 2005, s. 119.

25 Obliczenie na podstawie S. Ochmann-Staniszewska, Z. Staniszewski, Sejm Rzeczypospolitej za panowania Jana Kazimierza Wazy. Prawo - doktryna - praktyka, Wrocław 2000, t. 2, s. 32-34.

26 Częściowo rekompensują to sejmy grodzieńskie, obniżające statystykę, bowiem na żadnym z nich nie było więcej niż 20 wotujących, zob. R. Kołodziej, ,,Ostatni wolności naszej klejnot”,.., s. 220-221, tab. 11. 
ministrów. Z kolei na sejmie 1688-1689 mowy przerwano po jednym dniu, gdy głos zdążyło zabrać jedynie pięciu biskupów z jedenastu obecnych ${ }^{27}$.

Nawet przy pobieżnych obliczeniach należy uznać uzyskane dane za dość zaskakujące, a tak znacząca liczba wotujących jest swoistą zagadką. Tym bardziej, iż historycy zauważają, iż rola wotów w tym czasie zdecydowanie maleje ${ }^{28}$. Należy wziąć pod uwagę jednak, że te oceny dotyczą przede wszystkim zawartości merytorycznej wotów. Czy jednak dla ówczesnych to właśnie ona była najważniejsza? W omawianym okresie niezwykle ceniono przede wszystkim wartość retoryczną przemówień. Dobrych wotów uważnie słuchano, a wiele z nich zachowało się w szlacheckich sylwach jako wzory do nauki i naśladowania ${ }^{29}$. Wielu senatorów przygotowywało się do wotów długo i starannie, więc gdy dwukrotnie, ze względu na brak czasu, wotów nie dokończono, mieli o to pretensje ${ }^{30}$. Z wielką uwagą słuchano wotów prymasa Andrzeja Olszowskiego czy Stefana Wydżgi biskupa warmińskiego. Na sejmie koronacyjnym Jana III wystąpienie Władysława Reya odbywało się ,,przez godzin prawie dwie in altissimae silentiae [...] które godzinę w noc przy świecach kończył"31. $\mathrm{Na}$ wotum Stanisława Morsztyna kasztelana czerskiego wybierał się jeden z postronnych obserwatorów sejmu, Benedykt Olszewski, gdyż, jak sam zauważył: „wiem, że będzie się czego uczyć" 32 . Natomiast jeżeli wotum było słabe, mówione po cichu, w izbie panował czasem gwar, a zdarzało się nawet szlachcie wota przerywać. Na przykład w 1676 r. przerwano mowę Stefana Wierzbowskiego biskupa poznańskiego, ponieważ, gdy zapadł zmrok, biskup chciał wniesienia świec, na co posłowie nie wyrazili zgody. Biskup przerwał więc swe wystąpienie (chyba czytał je z karty) i urażony nie chciał go kończyć następnego dnia.

Wota były pierwszym obowiązkiem, jaki stał przed stanem senatorskim w trakcie obrad sejmowych. Po ponownym rozłączeniu stanów senatorowie brali udział w kolejnych czynnościach. Należał do nich przede wszystkim udział w sądach sejmowych, które powinny toczyć się zgodnie z konstytucją 1641 r. ${ }^{33}$ Aktualność tego prawa potwierdzono w czasach Jana III Sobieskiego na pierwszym sejmie grodzieńskim konstytucją „O remisach na sejm”, w której król deklarował sądzić remisy w przeznaczone do tego dni według regestru kancelarii ${ }^{34}$. Również i podczas tego sejmu senat zajął się inną kwestią związaną z funkcjonowaniem sądu sejmowego. Dotyczyła ona spisywania dekretów w sprawach kryminalnych i remisów z Trybunału, które zgodnie z prawem powinny być wpisywane do ksiąg

27 Recessus comitiorum Warsaviensium anni 1688 et 1689, AP Gdańsk, Recesy Stanów Prus Królewskich, 300,29/191, k. 38v-40; R. Kołodziej, ,, Ostatni wolności naszej klejnot”,.., s. 221, przyp. 319.

28 W. Czapliński, Sejm w latach 1589-1696, w: Historia sejmu polskiego, red. J. Michalski, Warszawa 1984, s. 260-261.

29 J. Ostrowski-Daneykowicz, Swada polska y tacińska albo miscellanea oratorskie, t. 1, Lublin 1745, zawiera mowy zarówno króla Jana III, jak i wielu senatorów, np. Stanisława Herakliusza Lubomirskiego, Krzysztofa Grzymułtowskiego, Andrzeja Kryszpina, Michała Radziejowskiego, Stanisława Szczuki, Jana Pieniążka, Andrzeja Olszowskiego, Kazimierza, Mikołaja, Franciszka oraz Benedykta Sapiehów, zob. s. 119-170, 180, 193, 195-197, 271, 291-292, 363-368.

30 R. Kołodziej, ,, Ostatni wolności naszej klejnot”,.., s. 220.

31 Compendium sejmu coronationis najjaśniejszego Jana III króla polskiego w Krakowie agitowanego anno Domini 1676, BOss., 247, k. 420v.

32 Benedykt Olszewski do Zbigniewa Morsztyna, Grodno, 20 III 1688, AGAD, AR V, 10816/III, s. 148; opinia dotyczyła wotum $\mathrm{z}$ rady posejmowej.

33 O porządku sądzenia spraw sejmowych, Volumina Constitutionum, do druku przygotował S. Grodziski i in. (dalej: VC), t. 4, vol. 1, s. 16-17.

34 VL, t. 5, s. 270. 
miejscowego sądu grodzkiego. Tymczasem w Grodnie funkcjonowała kancelaria, która nie znała się na przepisach prawa i procedurze koronnej. Doszło więc do sporu kompetencyjnego, gdyż do wpisywania dekretów swój akces zgłosiły sąd grodzki grodzieński oraz sąd grodzki warszawski. Ostateczną decyzję w tej sprawie podjął król wspólnie z radą senatu w dniu 11 stycznia 1679 r. Na jej mocy uznano, że dekrety będzie spisywał pisarz dekretowy koronny ${ }^{35}$. Innym problemem omawianych czasów, związanym z funkcjonowaniem sądu sejmowego, był częsty brak deputatów z izby poselskiej, która przez wiele tygodni nie potrafiła ich wyznaczyć. Problem ten starano się rozwiązać wspomnianą już wyżej konstytucją sejmową sejmu grodzieńskiego, która nakazywała marszałkowi wyznaczenie deputatów natychmiast po zakończeniu wotów senatorskich i rozłączeniu się stanów ${ }^{36}$. Zapisy te powtórzono w konstytucji $1690 \mathrm{r}$. normującej procedurę sejmową ${ }^{37}$. Mimo kolejnych uchwalanych praw, nie były one przez izbę przestrzegane, co powodowało, że sąd pracował często bez deputatów z izby poselskiej. Rolę asesorów podejmujących decyzję większością głosów ${ }^{38}$ pełnili więc wyłącznie senatorowie. Na koniec należy zwrócić uwagę, że dla wielu magnatów kwestie sądów sejmowych miały niebagatelne znaczenie, a wielu z nich uczestniczyło w procesach jako strony. Warto choćby przytoczyć jeden przykład. Jerzy Wandalin Mniszech wojewoda wołyński miał na sejmie 1690 r. procesy z „Horskim podkomorzym mińskim, Chodkiewiczem oboźnym litewskim, z Pacem kawalerem maltańskim, pisarzem litewskim, z Komorowskim bywszym podkomorzym a teraz marszałkiem wiłkomirskim, z Grodkowskim i inszymi osobami" 39 .

Kolejnym ważnym obszarem działań senatorów w czasie obrad sejmowych był udział w deputacjach, zarówno stałych, jak i nadzwyczajnych. Senatorów do deputacji mianował król, przestrzegając przy tym zasady równej reprezentacji wszystkich prowincji sejmowych. Nie na każdym sejmie deputacje funkcjonowały, ponieważ, w przeciwieństwie do sądów, bez mianowania deputatów z izby poselskiej nie mogły one rozpocząć pracy. Tymczasem deputatów z izby mianował marszałek, a tego nie zawsze udało się posłom wybrać. Obrady deputacji były dość sprawne, ponieważ odbywały się one w stosunkowo niewielkim gronie, w którym dużo szybciej można było osiągnąć kompromis. Jako że prace ich były tajne, o ich szczegółach nie zachowało się wiele informacji. Wiadomo jednak, że rola senatorów w deputacjach była duża. Jeden z nich zawsze przewodził obradom, z ich efektów relację przed całym sejmem składał także senator. Z nieoficjalnych informacji wiadomo, że podskarbiowie przedstawiający rozliczenia rachunków państwowych zabiegali u króla o powołanie do

\footnotetext{
35 Senatus consilium, Grodno, 11 I 1679 r., AGAD, AZ, 3046, s. 293-296. Taka sama decyzja zapadła podczas sejmu w Brześciu Litewskim w 1653 r.

${ }_{36}$ VL, t. 5, s. 270. Jako iż w konstytucji tej znalazł się zapis, że król powinien wybrać deputatów „nemine obstante contradictione", na sejmie 1683 r. konstytucję zmieniono, a powyższy fragment anulowano, zob. Deklaracya konstytucyi grodzieńskiej o remisach, VL, t. 5, s. 321-322.

37 „My zaś z radami naszemi, y deputowanemi z Izby Poselskiey Posłami, których, powróciwszy się do Izby Urodz. Marszałek Poselski deputować powinien, według dawnych praw, y zwyczaiów sprawy Seymowe sądzić będziemy”, zob. Obiaśnienie konstytucyi dawnieyszych o porządku seymowania, VL, t. 5, s. 371.

38 Omówienie prac sądu sejmowego zob. S. Szcząska, Sąd sejmowy w Polsce od końca XVI do końca XVIII wieku, „Czasopismo Prawno-Historyczne”, 20/1968, s. 421-436; S. Ochmann-Staniszewska, Z. Staniszewski, op. cit., t. 2, s. 215-218.

39 Justynian Towiański do J. Mniszcha, Warszawa, 14 III 1690, AGAD, Archiwum Roskie, Korespondencja, Pudło 36, nr 188.
} 
deputacji skarbowej przychylnych sobie kolegów z senatu ${ }^{40}$. Dwóch członków senatu było wyznaczanych do deputacji do konstytucji, która miała prowadzić prace redakcyjne nad uchwalonymi na sejmie prawami i podać je do druku. Również i w przypadku tej deputacji można podejrzewać, że rola senatorów była niemała, choć szczegółów na ten temat w źródłach brak. Najczęściej o fałszerstwa i nadużycia oskarżano deputatów z izby poselskiej, z tego też powodu na sejmie 1678-1679 r. wprowadzono obowiązek przysięgi deputatów, jednak jedynie z izby poselskiej - senatorowie składali wszak przysięgę przy obejmowaniu swojego urzędu ${ }^{41}$.

Ważnym elementem aktywności senatorskiej był udział w sesjach prowincji. Składały się one z posłów oraz senatorów poszczególnych części Rzeczypospolitej. Najczęściej w omawianym czasie obradowały sesje litewskie. Zdarzało się nawet, że Litwini przez kilkanaście dni potrafili nie pojawiać się na obradach plenarnych, dyskutując jedynie w swoim gronie. Niestety w diariuszach sejmowych na temat przebiegu debat na sesjach brakuje dokładnych informacji. Nie ulega jednak wątpliwości, że podczas tego typu prac, przy obecności mniejszej liczby posłów, zdanie senatorskie było z pewnością ważne. Nie bez znaczenia był fakt, że przewodniczyli sesjom senatorowie - na litewskich jeden z pieczętarzy, na koronnych najwyższy funkcją senator (a więc najczęściej jeden z biskupów). Sesje miały niekiedy znaczenie dla uspokojenia obrad i obniżenia ich temperatury. Król mógł za pomocą oddanych sobie senatorów wpłynąć na posłów i skłonić ich do swoich racji. Tak było choćby w 1683 r., gdy podczas sesji prowincji przekonano wszystkich posłów do sojuszu z cesarzem. Warto zauważyć również, że w przeciwieństwie do części opinii szlacheckich krytykujących sesje, wśród senatorów znaleźć można bardzo pochlebne opinie na temat ich funkcjonowania. Wyróżnia się na ich tle zdanie biskupa kijowskiego Andrzeja Chryzostoma Załuskiego, który w swoim wotum sejmowym w 1690 r. postulował częste zwoływanie sesji dla odciążenia obrad plenarnych ${ }^{42}$.

Wreszcie wykorzystywani byli senatorowie do komunikowania się z izbą poselską. Poselstwo z senatu przyjmowane było z dużymi honorami. Delegacja każdorazowo witana była przez marszałka specjalną mową, a po przedstawieniu celu wizyty, marszałek komunikował się z kolejnymi województwami i ziemiami, po czym odpowiadał przybyłym w imieniu izby. W bardziej skomplikowanych materiach odpowiedź odkładano do następnego dnia. Senatorowie mogli udać się do posłów wyłącznie na żądanie króla, w przeciwnym razie ich wizyta była bezprawna. W 1693 r. do sali poselskiej przybyli Jan Pieniążek wojewoda sieradzki oraz Kazimierz Opaliński biskup chełmiński ze skargą na królewskiego faktora, Żyda Jakuba Becala. Okazało się jednak, że zrobili to bez zgody i wiedzy króla, co izba poselska uznała za obraźliwe dla monarchy ${ }^{43}$. Poselstwa z senatu do izby miały najczęściej charakter mobilizująco-dyscyplinujący. Senatorowie na polecenie króla mieli przypominać

\footnotetext{
40 Taką prośbę do króla skierował Jan Andrzej Morsztyn podskarbi koronny, zob. J. A. Morsztyn do Jana III, Warszawa, 30 X 1676 r., w: S. Ochmann-Staniszewska, Listy Jana Andrzeja Morstina, Wrocław 2002, s. 310; o odpowiedni dobór deputatów do skwitowania zmarłego podskarbiego Marcina Zamoyskiego czynił starania jego sukcesor, Kazimierz Zamoyski wojewoda bełski, zob. K. Zamoyski do NN, Warszawa, 2 II 1690 r., Archiwum PAN, Teki Janusza Wolińskiego, 71, k. 9-9v.

41 „Iurament urodzonego Marszałka Poselskiego y Urodzonych Deputatów do Konstytucyi”, VL, t. 5, s. 267; w konstytucji zapisano, że do przysięgi są zobowiązani „deputaci z izby poselskiej do konstytucyi mianowani”.

42 Wotum Andrzeja Załuskiego biskupa kijowskiego i czernihowskiego na sejmie warszawskim 28 I 1690 r. miane, BN, III.6680, k. 75.

43 A. Kaźmierczyk, Sejm grodzieński, 31 grudnia 1692 - 11 lutego 1693, „Studia Historyczne”, 33/1990, s. 30.
} 
wiecznie spóźnionym posłom, aby przystępowali do kolejnych elementów procedury sejmowej. W czasach Jana III było to na tyle istotne, że ówczesne sejmy charakteryzowały się bardzo małą sprawnością, a uzyskanie konsensusu na przeprowadzenie w izbie prostej czynności zabierało posłom bardzo wiele czasu. Upominał się więc król o szybszy wybór marszałka, przybycie posłów na słuchanie propozycji od tronu i wotów senatorskich, wyłonienie członków deputacji i sądów, ustalenia listy wakansów. Zwyczajowo na pięć dni przed ustawowym końcem sejmu król powinien przysłać do izby senatorów zapraszających na konkluzję. W czasach Jana III nie było to normą, bowiem zdarzało się, że przed tym terminem nie udało się izbie wybrać marszałka, a dwukrotnie termin konkluzji przypadł na okres słuchania wotów senatorskich.

Ostatnim etapem sejmu miała być konkluzja, która zgodnie z prawem uchwalonym w 1633 r. powinna trwać ostatnie pięć dni ${ }^{44}$. Zgodnie z teorią posłowie powinni pojawić się w senacie z przygotowanymi, uzgodnionymi projektami, aby odczytać je w obecności króla i senatorów, zaakceptować i przekształcić w konstytucje. Teoria ta nie znajdowała właściwie zastosowania w czasach Jana III. O ile udało się kilka razy rozpocząć konkluzję w przewidzianym prawem terminie, to zakończyć nie udało się nigdy. Wszystkie sejmy z omawianych czasów były wielokrotnie prolongowane i zamiast przewidzianych prawem 45 , obradowały niejednokrotnie ponad 100 dni. To oznaczało, że konkluzja trwała nie pięć dni, ale niejednokrotnie ponad dwa miesiące. Dodatkowo bardzo często posłowie przychodzili do senatu, nie mając jeszcze przygotowanych żadnych projektów. Wszystko to powodowało, że właściwe obrady nad tworzeniem prawa odbywały się właśnie w trakcie konkluzji, więc automatycznie senatorowie stawali się członkami debaty na temat tworzonego prawa. Z jednej strony dawało to „braciom starszym” większą możliwość ingerowania w tworzone projekty. $\mathrm{Z}$ drugiej jednak, jako uczestnicy dyskusji, często musieli opowiadać się po którejś stronie i angażować w konflikty, a nawet otwarcie kwestionować przedstawiane projekty, co nie było korzystne dla senatorskiego prestiżu i obniżało rolę senatu jako stanu pośredniczącego między posłami i królem. Zauważali to niektórzy statyści, jak Stanisław Herakliusz Lubomirski, który dowodził, że zgodnie z prawem w senacie powinno się prawo co najwyżej poprawiać, ale nie stanowić ${ }^{45}$.

Zgodnie z oczekiwaniami szlachty senatorowie winni być jednocześnie strażnikami prawa, stanem pośredniczącym między szlachtą i królem, i mediatorami potrafiącymi uspokoić spory między posłami. Gdy w 1681 r. w izbie poselskiej toczyła się wspomniana wyżej debata nad możliwością objęcia urzędu kanclerskiego przez osobę duchowną, Wojciech Breza starosta nowodworski jako autorytet wskazywał właśnie senat, który, jego zdaniem, jest władny „,condere legem et interpretari”"46. W 1685 r. Litwini swój memoriał dotyczący naruszenia prawa w zakresie zwoływania sejmów grodzieńskich oddali senatorom koronnym: Stanisławowi Lubomirskiemu marszałkowi wielkiemu, Janowi Wielopolskiemu kanclerzowi i Janowi Gnińskiemu podkanclerzemu. Oburzenie części posłów wywołała delegacja senatu, która w 1676 r prosiła o zgodę na jednorazowe ominięcie zasady inkompatybiliów, gdy król chciał połączyć pieczęć z biskupstwem warmińskim. Można było usłyszeć wówczas głosy,

44 „Konkluzya sejmowa”, VC, t. 3, vol. 2, s. 197.

45 Stanisław Herakliusz Lubomirski marszałek wielki koronny do Michała Kazimierza Paca wojewody wileńskiego, z Jazdowa, 9 XI 1679, BN, BOZ, 1176, s. 52v-54v.

46 Diariusz sejmu walnego koronnego zaczynającego się w Warszawie dnia 14 ianuarii roku Pańskiego 1681, AGAD, APP, 323, s. 15. 
że senat, który jest strażnikiem prawa, sam namawia do jego łamania. Często szlachta wspominała również o roli pośrednika między królem i posłami. W wielu instrukcjach przedsejmowych można znaleźć zwroty, aby w razie konfliktów między stanami posłowie udawali się po pomoc do senatu. Wreszcie występują senatorowie jako element łagodzący napięcia między posłami. W obradach ówczesnego sejmu można podać bardzo wiele przykładów, gdy senatorowie prośbami i perswazjami próbowali skłonić posłów do ustępstw czy wycofania złożonych protestów. Przynosiło to zresztą różne efekty ${ }^{47}$. Z pewnością czynnikiem, który wpływał negatywnie na autorytet senatorów, a co za tym idzie, możliwości ich działania, były otwarte i demonstracyjnie okazywane konflikty między nimi. Wymienić ich tu wszystkich nie sposób, ale kłótnie na forum sejmu Michała Kazimierza Paca z Michałem Kazimierzem Radziwiłłem czy z Benedyktem Sapiehą (która o mało nie skończyła się pojedynkiem) na początku rządów Sobieskiego, Dominika Radziwiłła z Marcjanem Ogińskim w połowie panowania drugiego króla-rodaka, czy Kazimierza Sapiehy z Konstantym Brzostowskim przy końcu rządów bohatera spod Wiednia, nie dodawały senatorom powagi. Nie dodawało też wdawanie się w słowne utarczki podczas obrad, jak wzajemne obrzucenie się inwektywami przez Konstantego Brzostowskiego biskupa wileńskiego z Kazimierzem Dąbrowskim posłem wileńskim ${ }^{48}$. Wreszcie nie pomagały też działania stronników dworu, którzy potrafili na forum sejmu niezwykle ostro atakować senatorów za wypowiedzi uznane za nieprzychylne wobec króla, jak w przypadku Kazimierza Opalińskiego biskupa chełmińskiego, potraktowanego w sposób co najmniej nieparlamentarny za niezręczne sformułowanie użyte w wotum, kiedy, krzycząc, kazano mu na klęczkach przepraszać króla.

Spory wśród senatorów nie pozwalały im odegrać większej roli w sytuacjach nadzwyczajnych, kiedy ich rola mogła być kluczowa. Do takich zaliczyć należy zwołanie sejmu na dzień 22 grudnia 1693 r. ${ }^{49}$ Ponieważ król rozchorował się i nie był w stanie przybyć z Żółkwi na początek obrad, chciał przełożenia sejmu na późniejszy termin. Mieli to w jego imieniu zrobić senatorowie i należy uznać, że zdecydowanie nie potrafili udźwignąć ciężaru przekonania posłów, przede wszystkim litewskich. Szczególnie negatywnie wyróżnił się prymas Michał Radziejowski, który, zasłaniając się chorobą, w ogóle nie przybył do Warszawy, mimo ponagleń ze strony króla i innych senatorów. Oczywiście na bezowocne zakończenie jednodniowych obrad największy wpływ miały konflikty stronnictwa dworskiego z Sapiehami, którzy byli głównymi inspiratorami szybkiego zakończenia sejmu. Mało intensywne perswazje obecnych senatorów nie były w stanie przekonać sapieżyńskich ,partyzantów”.

Oceniając pozycję senatu i senatorów w czasach Jana III, można zwrócić uwagę na dwa czynniki. Z jednej strony dochodzi do uspokojenia nastrojów antysenatorskich, tak charakterystycznych dla końca panowania Jana Kazimierza, bezkrólewia w 1668 r. i rządów Michała Korybuta. Do wydarzeń tak radykalnych, jak ostrzelanie szopy senatorskiej podczas elekcji 1668 r. czy porąbanie na sejmiku w Środzie Krzysztofa Grzymułtowskiego

47 Przykłady tego typu działań zob. R. Kołodziej, ,, Ostatni wolności naszej klejnot”..., s. 320-321.

48 Kłótnia doprowadziła do rzucenia na Warszawę interdyktu przez prymasa M. Radziejowskiego, zob. Interdykt po rozerwanym sejmie anni 1689 z okazji jmci Brzostowskiego biskupa wileńskiego w Warszawie wydany, 2 IV 1689, BN, III.6680, k. 45v-46.

49 Szerzej wydarzenia tego sejmu zob. R. Kołodziej, Sejm z 22 grudnia 1693 roku, „Wieki Stare i Nowe”, 10/2016, s. 47-76. 
kasztelana poznańskiego, w tym okresie nie dochodzi ${ }^{50}$. Nie oznacza to jednak, że senat jako instytucja cieszył się bardzo wysokim autorytetem, który mógłby wpłynąć na poprawę jakości sejmowania. Kwestionowanie i kontestowanie decyzji rad senatu przez szlachtę potwierdza tę tezę ${ }^{51}$. Na zakończenie warto dodać jedynie, że nawet największe autorytety parlamentarne były bezradne w sytuacji, w której coraz więcej posłów związanych było z poszczególnymi fakcjami magnackimi i w swych działaniach brało pod uwagę przede wszystkim decyzje swoich mocodawców.

\section{Bibliografia}

\section{Rękopisy}

Archiwum Główne Akt Dawnych w Warszawie:

Archiwum Publiczne Potockich, 163, t. 3, 315, 323;

Achiwum Radziwiłłów, dz. II, ks. 29; dz. V, 12776, AGAD, 10816/III;

Archiwum Zamoyskich, 3046;

Archiwum Roskie, Korespondencja, Pudło 36, nr 188.

Archiwum Polskiej Akademii Nauk w Warszawie:

Teki Janusza Wolińskiego, 71.

Archiwum Państwowe w Gdańsku:

Recesy Stanów Prus Królewskich, 300,29/191.

Biblioteka Książąt Czartoryskich w Krakowie: 175, 176, 178.

Biblioteka Narodowa w Warszawie: III.6680.

Biblioteka Ordynacji Zamoyskich, 1176.

Biblioteka Zakładu Narodowego im. Ossolińskich we Wrocławiu: 247, 1767.

Biblioteka Uniwersytetu Wrocławskiego: 47.

Lietuvos mokslų akademijos Vrublevskių biblioteka: Fond 17-177.

Muzeum Narodowe w Krakowie: 169.

\section{Wydawnictwa źródłowe}

Ostrowski-Daneykowicz J., Swada polska y tacińska albo miscellanea oratorskie, t. 1, Lublin 1745.

Volumina Constitutionum, t. 3, vol. 2, do druku przygotowali S. Grodziski, M. Kwiecień, A. Karabowicz, przedmowa W. Uruszczak, Warszawa 2013.

Volumina Constitutionum, t. 4, vol. 1, do druku przygotował S. Grodziski M. Kwiecień,

K. Fokt, przedmowa W. Uruszczak, Warszawa 2015.

Volumina Legum, wyd. J. Ohryzko, t. 5, Petersburg 1860.

\footnotetext{
50 Nie oznacza to, że nie dochodziło w ferworze walki politycznej do utarczek słownych czy nawet przemocy fizycznej. Być może najbardziej dramatyczne wydarzenia miały miejsce na sejmiku gromnicznym w Rosieniach w 1696 r., gdzie przewodzącego obradom biskupa żmudzkiego Jana Hieronima Kryszpina Kirszensteina przewrócono razem z krzesłem, a następnie zmuszono do ucieczki z koła; opis wydarzeń zob. Lietuvos mokslų akademijos Vrublevskių biblioteka, Fond 17-177, k. 61-61v.

51 Jedną z najbardziej krytykowanych decyzji rad senatu było przełożenie sejmu z Grodna do Warszawy w 1685 r., co nie zostało uznane przez stronę litewską, zob. R. Kołodziej, Litewski sejmik generalny w Słonimiu na tle sytuacji w Rzeczypospolitej przed sejmem 1685 roku, ,Res Historica”, 40/2015, s. 97-113.
} 


\section{Monografie}

Ciara S., Senatorowie i dygnitarze koronni w drugiej połowie XVII wieku, Wrocław-Warszawa-Kraków 1990.

Czapliński W., Filipczak-Kocur A., Udziat senatorów w pracach sejmowych za Zygmunta III $i$ Wtadysława IV, „Przegląd Historyczny”, 69/1978, s. 670-675.

Czapliński W., Sejm w latach 1589-1696, w: Historia sejmu polskiego, red. J. Michalski, Warszawa 1984, s. 260-261.

Dąbrowski J., Senat koronny. Stan sejmujący w czasach Jana Kazimierza, Kraków 2000.

Hołdys S., Praktyka parlamentarna za panowania Władysława IV, Wrocław 1991.

Kawecki R., Kardynat Michat Stefan Radziejowski (1645-1705), Opole 2005.

Kaźmierczyk A., Sejm grodzieński, 31 grudnia 1692 - 11 lutego 1693, „Studia Historyczne”, 33/1990, s. 21-36.

Kołodziej R., ,,Ostatni wolności naszej klejnot”. Sejm Rzeczypospolitej za panowania Jana III Sobieskiego, Poznań 2014.

Kołodziej R., Litewski sejmik generalny w Stonimiu na tle sytuacji w Rzeczypospolitej przed sejmem 1685 roku, „Res Historica”, 40/2015, s. 97-113.

Kołodziej R., Sejm z 22 grudnia 1693 roku, „Wieki Stare i Nowe”, 10/2016, s. 47-76.

Korytko A., „Na których opiera się Rzeczpospolita”. Senatorowie koronni za Wtadystawa IV Wazy, Olsztyn 2015.

Krupa J., Rady senatu za Jana III Sobieskiego (1674-1696), „Studia Historyczne”, 35/1992, s. 305-329.

Kutrzeba S., Skład sejmu polskiego 1493-1793, „Przegląd Historyczny”, 2/1906, s. 43-76.

Maroń J., Senatorowie na sejmach Jana III, w: Z przeszłości Rzeczypospolitej w czasach nowożytnych, red. K. Matwijowski, S. Ochmann-Staniszewska, B. Rok, Wrocław 1998, „Prace Historyczne”, t. 25, s. 46-64.

Maroń J., Udziat senatorów w obradach sejmowych za panowania Jana III Sobieskiego, w: Senat w Polsce. Dzieje i teraźniejszość, red. K. Matwijowski, J. Pietrzak, Warszawa 1993, s. 221-231.

Matwijowski K., Senat w czasach Jana III Sobieskiego, w: Senat w Polsce. Dzieje i teraźniejszość, red. K. Matwijowski, J. Pietrzak, Warszawa 1993, s. 117-124.

Ochmann-Staniszewska S., Listy Jana Andrzeja Morstina, Wrocław 2002.

Ochmann-Staniszewska S., Staniszewski Z., Sejm Rzeczypospolitej za panowania Jana Kazimierza Wazy. Prawo - doktryna - praktyka, t. 1-2, Wrocław 2000.

Paradowski P., ,,W obliczu nagłych potrzeb” Rzeczypospolitej. Sejmy ekstraordynaryjne za panowania Władysława IV Wazy, Torun 2005.

Pietrzak J., Senat Rzeczypospolitej Polskiej. Tradycja i współczesność XV-XXI w., Warszawa 2010.

Rachuba A., Pac Mikołaj Stefan h. Gozdawa, w: Polski Stownik Biograficzny, t. 24, Wrocław-Warszawa-Kraków-Gdańsk 1979, s. 740.

Szcząska S., Sąd sejmowy w Polsce od końca XVI do końca XVIII wieku, „Czasopismo Prawno-Historyczne", 20/1968, s. 421-436.

Urzędnicy inflanccy XVI-XVIII w. Spisy, opr. K. Mikulski, A. Rachuba, Kórnik 1994.

Wierzbicki L., Senatorowie koronni na sejmach Rzeczypospolitej w XVII wieku, Warszawa 2017. 